\title{
Differences in risky sexual behaviors and HIV prevalence of circumcised and uncircumcised men in Uganda: evidence from a 2011 cross-sectional national survey
}

\author{
Simon PS Kibira ${ }^{1 *}$, Elizabeth Nansubuga ${ }^{2}$, Nazarius M Tumwesigye ${ }^{1}$, Lynn M Atuyambe ${ }^{1}$ and Fredrick Makumbi ${ }^{1}$
}

\begin{abstract}
Background: Safe male circumcision (SMC) is a known efficacious intervention in the prevention of heterosexual HIV acquisition. However, there are perceptions that SMC may lead to behavior disinhibition towards risky sexual behaviors. We assessed the association between male circumcision, risky sexual behaviors and HIV prevalence among men in a nationally representative sample.

Methods: Data was extracted from the Uganda AIDS Indicator Survey (2011), a stratified two-stage cluster sample, with a total of 7,969 ever sexually active men aged 15-59 years. The association between risky sexual behaviors (non- marital/non-cohabiting sexual relations, non-use of condoms, transactional sex, multiple (4+) lifetime partners) and male circumcision status were determined using odds ratios (OR) and their $95 \%$ confidence intervals, through logistic regression models. All analyses were conducted in Stata version 12.

Results: Overall, the prevalence of male circumcision was 28\%; higher among men aged 25-34 years, 32\%, and lowest among those aged 45-59 years, $18 \%$. HIV prevalence was significantly lower among the circumcised, 4.8\% compared to the uncircumcised men, 7.8\% ( $p<0.001)$. The commonest risky sexual behaviors were multiple life-time sexual partners (4+), 59\%; non-use of condoms with non-marital sexual partners, 55\%; and having non-marital sex, 33\%. In comparison with the uncircumcised, circumcised men had higher odds of engaging in non-marital sex AOR $=1.26$ (95\% Cl: 1.05-1.52), reporting multiple (4+) life-time partners, $A O R=1.46$ (95\% Cl: 1.27-1.67). The odds of non-use of condoms with a non-marital partner were also significantly lower among the circumcised compared to the uncircumcised men, $\mathrm{AOR}=0.79$ (95\% Cl: 0.63-0.98).

Conclusions: Although risky sexual behaviors were more common among circumcised men, HIV prevalence was lower among the circumcised men relative to the uncircumcised. These observations suggest a need to promote the already known HIV intervention strategies especially among the circumcised men.
\end{abstract}

Keywords: Safe male circumcision, Risky sexual behavior, HIV, Men, Uganda

\section{Background}

Male circumcision is the surgical removal of the foreskin of the human penis. Foreskin is one of the risk factors for Human Immunodeficiency Virus (HIV) acquisition from infected women to men [1]. Circumcision is practiced for religious, cultural, social as well as medical reasons in various settings [2]. The three randomized

\footnotetext{
* Correspondence: pskibira@gmail.com

'School of Public Health, Makerere University, Kampala, Uganda

Full list of author information is available at the end of the article
}

clinical trials (RCTs) of male circumcision conducted in sub-Saharan Africa; Uganda [3], Kenya [4] and South Africa [5], showed an average of $60 \%$ reduction in HIVacquisition. Other benefits of medical male circumcision included a lower risk of sexually transmitted infections (STIs) such as female genital ulcerations, bacterial vaginosis, trichomoniasis, human papilloma virus and chlamydia in female partners [3,6-8]. Based on these study findings, the World Health Organization and Joint United Nations Program on HIV/AIDS in 2007 recommended 
the adoption of male circumcision as part of the comprehensive strategy to reduce heterosexually acquired HIV infection in countries with high HIV prevalence and lower levels of male circumcision [9].

Although male circumcision was primarily practiced for religious and cultural reasons in Uganda, a safe male circumcision (SMC) policy was launched in 2010 as part of the comprehensive strategy on HIV prevention to complement the "ABC" strategy (abstinence, being faithful to one partner and condom use). The goal of the SMC policy is to contribute to the reduction of HIV and other STIs [2], and to establish a research agenda focusing on male circumcision services towards HIV prevention as one of the key objectives. This policy also recommends the integration of SMC services in the HIV prevention and sexual and reproductive health care services, while targeting all males including neonates whose parents and/or guardians consent to the procedure.

As a result of the policy, several strategies including limited offer of free circumcision at public health facilities, mobilization and sensitization of the population have been put in place to scale-up SMC in Uganda. Furthermore, in light of the research agenda of the policy, studies $[10,11]$ have also been undertaken to provide evidence based information useful in future programming of circumcision programs or services in the country.

Although Uganda recorded a slight increase in the percentage of circumcised adult males aged 15 - 59 years from $25 \%$ in 2004 to $27 \%$ in 2011 , the overall adult HIV prevalence increased from $6.4 \%$ to $7.3 \%$, and from $5.4 \%$ to $6.1 \%$ in adult men in the same period $[12,13]$. This increase has been associated with improved survival of HIV-infected persons who are enrolled in HIV-care and treatment [12], and the increase in risky sexual behavior (RSB) defined as concurrent multiple partnerships, non-consistent condom use with non-marital and noncohabiting partners, use of alcohol just before sex and transactional sex .

Increases in RSB may be explained by behavior risk compensation where people tend to adjust their behavior in response to the perceived level of risk. Usually people behave less cautiously when they feel more protected and become more cautious when they feel a higher level of risk. Because SMC is promoted as one of the prevention methods for HIV, there is a possibility of some people perceiving it as very highly protective [14] against HIV infection. In this context, it is possible that negative sexual behavior changes [15-17] may result among circumcised men $[18,19]$.

Although the increase in HIV prevalence has been partly explained by improved survival of HIV+ persons in care, anecdotal reports suggest an increase in RSB. However, the role of SMC on the increase in RSB is not clearly known, even as SMC policy is implemented in Uganda. We therefore compare sexual behaviors and HIV prevalence between circumcised and noncircumcised men from a nationally representative sample in Uganda.

\section{Methods}

Data are drawn from the 2011 Uganda AIDS Indicator Survey (AIS), a nationally representative sample obtained from a stratified two-stage cluster sampling strategy [12]. Clusters were selected from each stratum at the first stage, while the second stage involved selecting households for interview to obtain eligible respondents. The strata were defined as urban/rural and sub-regions while the clusters were enumeration areas as of the 2010 Uganda National Household Survey updates [12]. Data for this survey were collected between February and September 2010, led by the Ministry of Health working with ICF international, USA and Uganda Bureau of Statistics. Interviews obtained data on respondent's self-reported male circumcision status, sexual behaviors and social-demographic characteristics (age, marital status, highest education level, survey region, ethnicity, residence, religion and the wealth status of the households). HIV status was tested from blood samples obtained during the interviews from consenting respondents. Data from individual interview and HIV-status were linked by unique identifiers for each individual respondent. Of the 9,524 men aged 15-59 years, a total of 7969 (84\%) ever sexually active men were linked to their HIV-status.

Risky sexual behavior was defined and grouped into four categories; i) transactional sex (payment or receipt of money/gift in exchange for sex) in the preceding 12 months of the survey, ii) life-time number of sexual partners, with $1-3$ as the referent and 4 or more partners, based on the median life-time partners, 4 , iii) nonmarital sexual relations (include non-cohabiting partners), and iv) non-use of condoms with the last non-marital partner in the last 12 months. The definition of "non marital sex" is based on the UAIS (2011) and includes all men whether married or not, who were sexually active in the 12 months preceding the survey reporting having sex with a non-marital non cohabiting partner. "Condom use at last non marital sex" only included men who reported that they had non-marital sex in the preceding 12 months.

The outcome variables were the four RSBs, all coded either as ' 0 ': when the behavior was not reported and ' 1 ': when the behavior was reported, and for life-time partners coded as ' 0 ': if reported as 1-3 lifetime partners and ' 1 ': if $4+$ partners were reported. The primary independent variable was self-reported male circumcision status, and social-demographic characteristics as other explanatory variables. 
Table 1 Respondents' characteristics and HIV status

\begin{tabular}{|c|c|c|c|c|}
\hline & $\begin{array}{c}\text { All men } \\
\text { n (\%) }\end{array}$ & $\begin{array}{c}\text { Circumcised } \\
\text { n (\%) }\end{array}$ & $\begin{array}{c}\text { Uncircumcised } \\
\text { n (\%) }\end{array}$ & $p$-value \\
\hline Overall & $7969(100)$ & $2228(100)$ & $5741(100)$ & \\
\hline \multicolumn{5}{|l|}{ Characteristics } \\
\hline \multicolumn{5}{|l|}{ Age group } \\
\hline $15-24$ & $1941(24.3)$ & $610(27.4)$ & $1331(23.2)$ & 0.046 \\
\hline $25-34$ & $2460(30.9)$ & $708(31.8)$ & $1751(30.5)$ & 0.527 \\
\hline $35-44$ & $2000(25.1)$ & $508(22.8)$ & $1492(26.0)$ & 0.151 \\
\hline $45-59$ & $1568(19.7)$ & $402(18.0)$ & $1166(20.3)$ & 0.317 \\
\hline \multicolumn{5}{|l|}{ Residence } \\
\hline Urban & 1520(19.1) & $604(27.1)$ & $916(16.0)$ & $<0.001$ \\
\hline Rural & $6449(80.9)$ & $1624(72.9)$ & $4825(84.0)$ & $<0.001$ \\
\hline \multicolumn{5}{|l|}{ Survey region } \\
\hline Central & $1784(22.4)$ & $491(22.0)$ & $1293(22.5)$ & 0.821 \\
\hline Kampala & $568(7.1)$ & $215(9.6)$ & $353(6.2)$ & 0.135 \\
\hline Eastern & $1701(21.3)$ & $882(39.6)$ & $819(14.3)$ & $<0.001$ \\
\hline Northern & $1999(25.1)$ & $201(9.0)$ & $1798(31.3)$ & $<0.001$ \\
\hline Western & $1916(24.0)$ & $439(19.7)$ & $1477(25.7)$ & 0.010 \\
\hline \multicolumn{5}{|l|}{ Highest education level } \\
\hline No education & $570(7.2)$ & $143(6.4)$ & $427(7.4)$ & 0.688 \\
\hline Primary & $4526(56.8)$ & $1166(52.3)$ & $3360(58.5)$ & $<0.001$ \\
\hline Secondary & $2155(27.0)$ & $697(31.3)$ & $1458(25.4)$ & 0.004 \\
\hline Post secondary & $718(9.0)$ & $222(10.0)$ & $496(8.6)$ & 0.545 \\
\hline \multicolumn{5}{|l|}{ Marital status } \\
\hline Never married & $1649(20.7)$ & $523(23.5)$ & $1127(19.6)$ & 0.070 \\
\hline Currently married & $5710(71.7)$ & $1534(68.9)$ & $4176(72.7)$ & 0.005 \\
\hline Divorced/seperated & $609(7.6)$ & $171(7.7)$ & $438(7.6)$ & 0.967 \\
\hline \multicolumn{5}{|l|}{ Ethnicity } \\
\hline Baganda & $1321(16.6)$ & $400(18.0)$ & $921(16.1)$ & 0.395 \\
\hline Banyakore & $794(10.0)$ & $109(4.9)$ & $685(11.9)$ & 0.030 \\
\hline Iteso/Karimojong & $730(9.2)$ & $64(2.9)$ & $667(11.6)$ & 0.032 \\
\hline Lugbara/Madi/Alur/Japadhola & $783(9.8)$ & $186(8.4)$ & $597(10.4)$ & 0.426 \\
\hline Basoga & $716(9.0)$ & $314(14.1)$ & $401(7.0)$ & 0.002 \\
\hline Langi/Acholi & $896(11.2)$ & $19(0.9)$ & $877(15.3)$ & 0.082 \\
\hline Bakiga & $427(5.4)$ & $42(1.9)$ & $385(6.7)$ & 0.222 \\
\hline Bagisu/Sabiny/ & $510(6.4)$ & $480(21.6)$ & $30(0.5)$ & 0.005 \\
\hline Bakonjo & $170(6.2)$ & $165(7.4)$ & $5(0.1)$ & 0.533 \\
\hline Banyoro/Batoro & $680(8.5)$ & $164(7.4)$ & $516(9.0)$ & 0.525 \\
\hline Bafumbira & $165(2.1)$ & $24(1.1)$ & $141(2.5)$ & 0.672 \\
\hline Bagwere/Samia & $280(3.5)$ & $99(4.4)$ & $181(3.2)$ & 0.607 \\
\hline Others & $497(6.2)$ & $163(7.3)$ & $335(5.8)$ & 0.518 \\
\hline \multicolumn{5}{|l|}{ Religion } \\
\hline Moslem & 1038 (13.0) & $1026(46.1)$ & $12(0.2)$ & $<0.001$ \\
\hline Non Moslem & $6931(87.0)$ & $1202(53.9)$ & 5729 (99.8) & $<0.001$ \\
\hline
\end{tabular}


Table 1 Respondents' characteristics and HIV status (Continued)

\begin{tabular}{|c|c|c|c|c|}
\hline \multicolumn{5}{|l|}{ HIV Status } \\
\hline Negative & 7416 (93.1) & $2120(95.2)$ & $5296(92.3)$ & $<0.001$ \\
\hline Positive & $553(6.9)$ & $108(4.8)$ & $445(7.8)$ & 0.280 \\
\hline \multicolumn{5}{|c|}{ Circumcision status } \\
\hline Yes & $2228(27.9)$ & & & \\
\hline No & $5741(72.0)$ & & & \\
\hline
\end{tabular}

\section{Statistical analysis}

Exploratory data analysis was conducted on all the variables of interest. In the bivariate analysis, cross tabulations were done to determine unadjusted associations between the outcomes (RSBs and HIV status), and circumcision status, and other covariates including socialdemographic characteristics. The statistical significance was determined using chi-square tests at the 5\% level. Odds ratios (OR) were used as the measure of association with their 95\% confidence intervals (CI). These were obtained through logistic regression models. For the adjusted analyses, all variables in the bivariate analysis that had $\mathrm{p}<0.15$, OR $>2$ or $\mathrm{OR}<0.5$ or known confounders in the association were included in the multivariable logistic regression model. Collinearity of independent variables in the model was assessed by use of the variance inflation factor (VIF) and tolerance in STATA, where only non-collinear variables were retained. All the models had circumcision status as the primary independent factor.

Social-demographic characteristics included in these analyses were residence, marital status, religion, education, wealth status, region, age, and ethnicity.

The analysis was weighted in order to account for the complex survey methodology using the 'svyset' command in STATA. The AIS was reviewed and approved by the Science and Ethics Committee of the Uganda Virus Research Institute, ICF International's Institutional Review Board, and a review committee at the Centers for Disease Control and Prevention in Atlanta. It was also cleared by the Ethics Committee of the Uganda National Council of Science and Technology. Permission to use this data was obtained from ICF international, USA.

\section{Results}

\section{Description of the respondents}

Table 1 shows respondents' characteristics. Nearly 4 in $5(81 \%)$ of the respondents were from rural areas, just over a half $(57 \%)$ had primary education, nearly three quarters $(72 \%)$ were either married or cohabiting, and almost a third (31\%) were aged 25-34 years. The largest tribal grouping were Baganda (17\%), and 13\% of Muslim religion. Twenty eight percent (46\% Muslim,
$54 \%$ non Muslim) of the respondents reported that they were circumcised.

In comparison to the uncircumcised, the circumcised men tended to be younger (age 15-24), from the urban areas, attained secondary education, Muslims, from eastern Uganda and of Bagisu, Sabiny and Basoga ethnicities, but did not differ by never married marital status.

HIV prevalence was $6.9 \%$ among all the men in the sample and the circumcised men were less likely to be HIV positive.

\section{Comparison of sexual behavior between circumcised and uncircumcised Men}

Table 2 shows the comparison of the prevalence of RSBs among circumcised and uncircumcised men. Overall, nearly a third (32.5\%) of the men reported non-marital sex in the last 12 months, and just over a half (55\%) reported non-use of condoms the last time they had such sex. The least reported RSB was transactional sex (3\%). All the four RSBs were most commonly reported among the circumcised men; nearly two thirds of circumcised compared to $56 \%$ of the uncircumcised men reported 4 or more life-time partners (p-value $<0.001$ ), while $38 \%$ of the circumcised compared to $30 \%$ of the uncircumcised reported non-marital sex (p-value $<0.001)$.

\section{Associations between circumcision status and sexual behaviors}

Table 3 shows both unadjusted and adjusted associations between the different RSBs and circumcision status. Four models were run using each RSB as an outcome, with circumcision status as the primary independent variable. In

Table 2 Comparison of risky sexual behaviors between circumcised and uncircumcised men

\begin{tabular}{lccc}
\hline & $\begin{array}{c}\text { Circumcised } \\
\mathbf{n ( \% )}\end{array}$ & $\begin{array}{c}\text { Uncircumcised } \\
\mathbf{n}(\%)\end{array}$ & $\begin{array}{c}\text { Overall } \\
\mathbf{n}(\%)\end{array}$ \\
\hline Risky sexual behavior & & & \\
Non-marital partners & $766(38.4)$ & $1547(30.2)$ & $2314(32.5)$ \\
Non-use of condoms & $319(58.4)$ & $728(52.9)$ & $1267(54.7)$ \\
Transactional sex & $74(3.7)$ & $139(2.7)$ & $214(3.0)$ \\
4+ lifetime partners & $1466(65.8)$ & $3239(56.4)$ & $4706(59.1)$ \\
\hline
\end{tabular}


Table 3 Unadjusted and Adjusted Odds ratios for risky sexual behaviors comparing circumcised and uncircumcised

\begin{tabular}{|c|c|c|c|c|}
\hline & (1) & (2) & (3) & (4) \\
\hline & $\begin{array}{l}\text { Number of lifetime } \\
\text { partners }\end{array}$ & $\begin{array}{l}\text { Had non marital sex the last } \\
12 \text { months }\end{array}$ & $\begin{array}{c}\text { Condom use at last non } \\
\text { marital sex }\end{array}$ & $\begin{array}{c}\text { Transactional sex in } \\
12 \text { months }\end{array}$ \\
\hline & ORs $(95 \% \mathrm{Cl})$ & ORs $(95 \% \mathrm{Cl})$ & ORs $(95 \% \mathrm{Cl})$ & ORs $(95 \% \mathrm{Cl})$ \\
\hline \multicolumn{5}{|l|}{ Circumcision status } \\
\hline \multicolumn{5}{|l|}{ Unadjusted } \\
\hline Uncircumcised & 1 & 1 & 1 & 1 \\
\hline Circumcised & $1.48^{?}(1.31,1.68)$ & $1.43^{*}(1.24,1.65)$ & $0.80^{*}(0.65,0.98)$ & $1.37(0.98,1.94)$ \\
\hline \multicolumn{5}{|l|}{ Adjusted } \\
\hline Uncircumcised & 1 & 1 & 1 & 1 \\
\hline Circumcised & $1.46^{?}(1.27,1.67)$ & $1.26^{*}(1.05,1.52)$ & $0.79^{*}(0.63,0.98)$ & $1.20(0.81,1.78)$ \\
\hline \multicolumn{5}{|l|}{ Background characteristics" } \\
\hline \multicolumn{5}{|l|}{ Age } \\
\hline $15-24$ & 1 & 1 & 1 & 1 \\
\hline $25-34$ & $1.81^{?}(1.52,2.16)$ & $0.74^{*}(0.57,0.95)$ & $0.86(0.64,1.14)$ & $0.71(0.42,1.18)$ \\
\hline $35-44$ & $3.12^{?}(2.56,3.79)$ & $0.61^{?}(0.46,0.78)$ & $0.66^{*}(0.44,0.96)$ & $0.66(0.37,1.16)$ \\
\hline $45-59$ & $4.26 ?(3.44,5.28)$ & $0.36^{?}(0.27,0.48)$ & $0.34^{?}(0.22,0.53)$ & $0.22^{?}(0.11,0.44)$ \\
\hline \multicolumn{5}{|l|}{ Ethnicity } \\
\hline Baganda & 1 & 1 & 1 & 1 \\
\hline Banyakore & $0.54^{?}(0.41,0.72)$ & $0.77(0.51,1.14)$ & $0.66(0.60,1.08)$ & $0.80(0.30,2.12)$ \\
\hline Iteso/Karimojon & $1.83(0.64,1.08)$ & $0.51^{?}(0.34,0.75)$ & $0.57^{*}(0.37,0.89)$ & $0.56(0.16,1.89)$ \\
\hline Lugbara/Madi/Alur/Japadhola & $0.82(0.62,1.09)$ & $0.62^{?}(0.44,0.88)$ & $0.92(0.87,2.45)$ & $1.79(0.81,3.95)$ \\
\hline Basoga & $1.32^{*}(1.03,1.69)$ & $1.17(0.73,1.86)$ & $0.46^{?}(0.30,0.70)$ & $1.34(0.44,4.02)$ \\
\hline Langi/Acholi & $0.88(0.67,1.15)$ & $0.53^{?}(0.37,0.75)$ & $0.79(0.51,1.20)$ & $0.20(0.05,0.78)$ \\
\hline Bakiga & $0.67^{*}(0.49,0.92)$ & $0.67(0.40,1.11)$ & $0.30^{?}(0.19,0.46)$ & $2.05^{?}(1.03,4.10)$ \\
\hline Bagisu/Sabiny & $1.06(0.76,1.66)$ & $0.58^{*}(0.34,0.98)$ & $0.40^{?}(0.25,0.63)$ & $0.99(0.37,2.65)$ \\
\hline Banyoro/Batoro & $1.41^{*}(1.06,1.88)$ & $1.61^{*}(1.12,2.32)$ & $0.50^{?}(0.33,0.76)$ & $2.47^{*}(1.21,5.07)$ \\
\hline Bafumbira & $0.32^{?}(0.18,0.55)$ & $0.43^{*}(0.20,0.89)$ & $0.25^{?}(0.09,0.71)$ & $0.27(0.03,2.47)$ \\
\hline Bagwere/Samia & $1.19(0.79,1.79)$ & $1.17(0.72,1.90)$ & $0.78(0.41,1.52)$ & $1.50(0.57,3.94)$ \\
\hline Bakonjo & $0.61^{*}(0.38,0.98)$ & $0.83(0.53,1.31)$ & $0.23^{*}(0.07,0.72)$ & $0.79(0.18,3.37)$ \\
\hline Others & $0.86(0.63,1.18)$ & $0.95(0.62,1.45)$ & $0.96(0.63,1.46)$ & $1.72(0.88,3.35)$ \\
\hline
\end{tabular}

\section{Wealth status}

Lowest quintile

2nd quintile

Middle

4th quintile

Highest quintile

\section{Marital status}

Never married

Married

Divorced/separated

Highest education level

No education

Primary
1

$1.30^{?}(1.09,1.53)$

$1.48^{?}(1.22,180)$

$1.61^{?}(1.34,1.93)$

$1.97^{?}(1.56,2.48)$

$2.29^{?}(1.90,2.75)$

$2.55^{?}(1.98,3.27)$

1

$1.46^{?}(1.17,1.83)$

$$
\begin{aligned}
& 0.77(0.51,1.14) \\
& 0.51^{?}(0.34,0.75) \\
& 0.62^{?}(0.44,0.88) \\
& 1.17(0.73,1.86) \\
& 0.53^{?}(0.37,0.75) \\
& 0.67(0.40,1.11) \\
& 0.58^{*}(0.34,0.98) \\
& 1.61^{*}(1.12,2.32) \\
& 0.43^{*}(0.20,0.89) \\
& 1.17(0.72,1.90) \\
& 0.83(0.53,1.31) \\
& 0.95(0.62,1.45)
\end{aligned}
$$

$1.31^{*}(1.00,1.72)$

$1.59^{?}(1.20,2.09)$

$2.02 ?(1.50,2.71)$

$1.98 ?(1.37,2.85)$

$0.01^{?}(0.00,0.01)$

$0.07^{?}(0.04,0.12)$

$1.07(0.78,1.46)$
$1.12(0.76,1.65)$

$1.40(0.95,2.06)$

$1.75 ?(1.17,2.62)$

$2.55^{?}(1.63,3.99)$

$1.35^{*}(1.04,1.77)$

$1.13(0.79,1.61)$

$0.72(0.41,1.29)$

$2.21^{*}(1.17,4.17)$

1

$2.18^{*}(1.13,4.21)$ 
Table 3 Unadjusted and Adjusted Odds ratios for risky sexual behaviors comparing circumcised and uncircumcised (Continued)

\begin{tabular}{|c|c|c|c|c|}
\hline$\overline{\text { Secondary }}$ & $1.42^{?}(1.09,1.86)$ & $1.06(0.74,1.52)$ & $3.14^{?}(1.63,6.04)$ & $0.67(0.24,1.86)$ \\
\hline Post secondary & $1.07(0.77,1.48)$ & $1.29(0.86,1.96)$ & $3.57^{?}(1.79,7.14)$ & $0.42(0.12,1.48)$ \\
\hline Number of men & 7,969 & 7,114 & 2,231 & 7,109 \\
\hline
\end{tabular}

the adjusted analysis we controlled for age, ethnicity, residence, wealth status, marital status, and education as covariates. In the final models, the variable region was dropped because it was found to be collinear with ethnicity, which was retained as a more important variable in explaining some of the key findings.

Male circumcision was significantly associated with increased odds of having non-marital sex, and reporting 4 + lifetime sexual partners. However, non-use of condoms was significantly lower among the circumcised compared to the non- circumcised. In models 2 and 3, the odds of having non marital sex in the last 12 months were 1.26 times higher among the circumcised men compared with the uncircumcised while non use of condoms at the last such sex was also significantly associated with circumcision status $(\mathrm{p}<0.05)$.

\section{Associations between circumcision status and HIV status}

Table 4 (Model 1) shows the adjusted association between HIV status and circumcision status, controlling for age, ethnicity, residence, wealth status, marital status, and highest level of education. Survey region was found to be collinear with ethnicity and thus dropped. In model two we controlled for both background characteristics as in model one, and two of the RSBs (number of lifetime sexual partners and transactional sex in the last 12 months). The other RSBs (non marital sex and condom use at last such sex were excluded because of collinearity). Results in model 1 indicate that the odds of being HIV positive among circumcised men were $35 \%$ lower compared with uncircumcised men after controlling for the five remaining background characteristics as indicated above, while in model 2, the odds of being HIV positive among circumcised men were $37 \%$ lower compared with uncircumcised men after controlling for both background characteristics and the two RSBs.

\section{Discussion}

The findings from our study indicate that over a quarter of men who were ever sexually active were circumcised and one third of these were aged between 25 to 34 years. The most common risky sexual behaviors were multiple life-time sexual partners $(4+)$, having non marital sex, and non-use of condoms during non marital sex. These were also significantly higher among the circumcised. Despite evidence of higher RSB among the circumcised men, we found lower HIV prevalence in this group compared to their uncircumcised counterparts.

Circumcised men had higher odds of having 4 or more life time sexual partners, engaging in non marital sex in the 12 months preceding the survey and non-condom use at last such sex than uncircumcised men. In a Zimbabwe study [20], circumcision was not associated with RSBs, but instead uncircumcised men who were willing to be circumcised had more risky behaviors, while in a post trial study in Rakai-Uganda [21], there was no evidence of risk compensation as well. However, our results are consistent with findings from another study [22], which showed that circumcised men had unprotected sexual intercourse and more sexual partners. Some studies attribute such unexpected differences in sexual behavior to the behavior risk compensation where men change their sexual behaviors with the knowledge that their risk of infection is reduced $[17,19,23]$. In the study by Riess et al. (2010), some men stopped using condoms temporarily after undergoing male circumcision as part of the new program in Kisumu (Kenya) while others increased the number of sexual partners, but the study overall reported no sexual behavioral disinhibition. In the South African RCT, circumcised men reported more sexual contacts than uncircumcised men at the 4- 12 month and in the 13 to 21 month recall periods [5]. The promotion of SMC without increased education and counseling of the men may hinder progress in further HIV reduction [24] as circumcised men had more RSBs. Even though there is no empirical evidence in this study to ascertain that the RSBs observed among the circumcised men were a result of risk compensation, it may be one of the possible explanations. Another possibility could be that men that already have RSBs decide to undergo circumcision to reduce their chances of HIV infection. These may not change behaviors post circumcision, but this needs more exploration.

In relation to circumcision and HIV status, results at both bivariate and multivariate levels showed that circumcised men were more likely to be HIV negative compared with the uncircumcised. This protective effect of circumcision is consistent with results from the 3 
Table 4 Adjusted Odds ratios for Circumcision status and HIV $^{+}$status

\begin{tabular}{|c|c|c|}
\hline & (1) & (2) \\
\hline & $\begin{array}{l}\text { HIV status, adjusted } \\
\text { for background } \\
\text { characteristics }\end{array}$ & $\begin{array}{l}\text { HIV status, adjusted } \\
\text { for background } \\
\text { characteristics and risk } \\
\text { sexual behaviors }\end{array}$ \\
\hline & ORs $(95 \% \mathrm{Cl})$ & ORs $(95 \% \mathrm{Cl})$ \\
\hline \multicolumn{3}{|l|}{ Circumcision status } \\
\hline Uncircumcised & 1 & 1 \\
\hline Circumcised & $0.65^{*}(0.47,0.90)$ & $0.63^{?}(0.45,0.87)$ \\
\hline \multicolumn{3}{|l|}{$\begin{array}{l}\text { Background } \\
\text { characteristics" }\end{array}$} \\
\hline \multicolumn{3}{|l|}{ Age } \\
\hline Age group & 1 & 1 \\
\hline $15-24$ & $2.21^{?}(1.27,3.81)$ & $2.08^{?}(1.21,3.57)$ \\
\hline $25-34$ & $3.91^{?}(2.27,6.71)$ & $3.49^{?}(2.05,5.93)$ \\
\hline $35-44$ & $2.73^{?}(1.57,4.79)$ & $2.38^{?}(1.37,4.12)$ \\
\hline \multicolumn{3}{|l|}{ Ethnicity } \\
\hline Baganda & 1 & 1 \\
\hline Banyakore & $1.42(0.85,2.39)$ & $1.50(0.90,2.51)$ \\
\hline Iteso/Karimojong & $1.35(0.77,2.39)$ & $1.35(0.75,2.42)$ \\
\hline $\begin{array}{l}\text { Lugbara/Madi/Alur/ } \\
\text { Japadhola }\end{array}$ & $1.14(0.59,2.22)$ & $1.13(0.58,2.21)$ \\
\hline Basoga & $1.24(0.69,2.22)$ & $1.20(0.67,2.16)$ \\
\hline Langi/Acholi & $1.53(0.80,2.95)$ & $1.57(0.81,3.06)$ \\
\hline Bakiga & $1.53(0.86,2.73)$ & $1.55(0.88,2.73)$ \\
\hline Bagisu/Sabiny & $1.50(0.77,2.92)$ & $1.43(0.74,2.77)$ \\
\hline Banyoro/Batooro & $1.51^{*}(1.00,2.27)$ & $1.56(0.99,2.47)$ \\
\hline Bafumbira & $0.95(0.47,1.91)$ & $1.15(0.57,2.33)$ \\
\hline Bagwere/Samia & $2.10(0.90,4.92)$ & $1.98(0.83,4.71)$ \\
\hline Bakonjo & $0.52(0.17,1.62)$ & $0.57(0.19,1.76)$ \\
\hline Others & $1.58(0.97,2.59)$ & $1.69^{*}(1.01,2.85)$ \\
\hline \multicolumn{3}{|l|}{ Marital status } \\
\hline Never married & 1 & 1 \\
\hline Currently married & $1.69(0.97,2.92)$ & $1.62(0.94,2.82)$ \\
\hline Divorced/separated & $4.13^{?}(2.34,7.28)$ & $3.65^{?}(2.10,6.32)$ \\
\hline \multicolumn{3}{|l|}{$\begin{array}{l}\text { Highest education } \\
\text { level }\end{array}$} \\
\hline \multicolumn{3}{|l|}{ No education } \\
\hline Primary & $1.11(0.72,1.71)$ & $1.07(0.71,1.64)$ \\
\hline Secondary & $0.95(0.58,1.56)$ & $0.95(0.59,1.53)$ \\
\hline Post secondary & $0.56^{*}(0.32,0.98)$ & $0.59(0.34,1.02)$ \\
\hline \multicolumn{3}{|l|}{ Wealth Status } \\
\hline Lowest quintile & 1 & 1 \\
\hline 2nd quintile & $1.10[0.79,1.52]$ & $1.06(0.77,1.47)$ \\
\hline Middle & $1.15(0.79,1.69)$ & $1.10(0.75,1.61)$ \\
\hline 4th quintile & $1.52^{*}(1.04,2.22)$ & $1.47(1.00,2.18)$ \\
\hline Highest quintile & $1.39(0.89,2.17)$ & $1.52^{*}(1.02,2.27)$ \\
\hline
\end{tabular}

Table 4 Adjusted Odds ratios for Circumcision status and HIV $^{+}$status (Continued)

\begin{tabular}{|c|c|c|}
\hline \multicolumn{3}{|c|}{$\begin{array}{l}\text { Transactional sex in } \\
\text { last } 12 \text { months }\end{array}$} \\
\hline Did not pay for sex & & 1 \\
\hline Paid for sex & & $2.17^{?}(1.29-3.66)$ \\
\hline \multicolumn{3}{|c|}{$\begin{array}{l}\text { Number of lifetime } \\
\text { partners }\end{array}$} \\
\hline Less than four & & 1 \\
\hline Four or more & & $1.75^{?}(1.40-2.20)$ \\
\hline Number of men & 7,969 & 7,969 \\
\hline
\end{tabular}

RCTs [3-5] that showed the same protection against heterosexual HIV transmission from infected women to men. More importantly in our study, this protective effect was observed even though the odds of RSBs were much higher among the circumcised men. This could mean that the negative effect of risk compensation in our context may be insignificant compared to the fundamental benefits of the SMC interventions in this population.

The limitations to this study are that: analysis is based on data from a cross-sectional survey design and thus not possible to establish causality using such data, the analysis was restricted to only men who were ever sexually active, while the circumcision status and sexual behaviours were self reported by participants.

\section{Conclusions}

Circumcision was strongly associated with RSB. However, HIV prevalence was significantly lower in circumcised men.

Safe male circumcision messages need to continue to emphasise the risk of HIV even after circumcision. Intensified individual tailored counseling pre and post $\mathrm{SMC}$ procedures may play a role in reducing these behaviors.

More sensitizations both at population level and at health facilities on the advantages of circumcision need to be done so as to encourage more men to get circumcised given the protective effect observed even amidst RSBs.

\section{Abbreviations}

ABC: Abstinence, being faithful and condom use; RCTs: Randomised controlled trials; AIDS: Acquired immune deficiency syndromme; AIS: AIDS indicator survey; HIV: Human immune virus; $\mathrm{MOH}$ : Ministry of health; RSB: Risky sexual behaviour; SMC: Safe male circumcision; STIs: Sexually transmitted infections.

Competing interests

The Authors declare that they have no competing interest. 


\section{Authors' contribution}

SPSK conceived the study, led the data analysis and writing process. EN substantially contributed to conceiving the study, participated in data analysis and writing. NMT participated in the analysis and writing. LMA contributed to the writing. FM contributed significantly to the analysis and writing. All authors read and approved the final manuscript.

\section{Authors' informations}

SPSK is a social and population scientist and an assistant lecturer at the school of public health, Makerere University.

EN is a population scientist and assistant lecturer at the school of statistics and planning, Makerere University.

NMT is a biostatistician and associate professor of epidemiology at the school of public health, Makerere University.

LMA is a social scientist and lecturer at the school of public health, Makerere University.

FM is a biostatistician and senior lecturer at the school of public health, Makerere University.

\section{Acknowledgements}

This paper was written using funding from the United States Agency for International Development through ICF International's DHS Program. The authors are grateful for input from Wenjuan Wang, Sarah Staveteig, Helen Nviiri for technical support in analysis of the data and Joy Fishel for reviewing the Manuscript. Special thanks to the peer reviewer.

\section{Author details}

${ }^{1}$ School of Public Health, Makerere University, Kampala, Uganda. ${ }^{2}$ School of Statistics and Planning, Makerere University, Kampala, Uganda.

Received: 19 December 2013 Accepted: 19 March 2014

Published: 24 March 2014

\section{References}

1. Wabwire-Mangen F, Odiit M, Kirungi W, Kaweesa K, David, Wanyama O, James: Uganda HIV Prevention Response and Modes of Transmission Analysis. Kampala: Uganda National AIDS Commission, UNAIDS; 2009.

2. Government of Uganda MOH: Safe Male Circumcision Policy. Kampala: Ministry of Health ed; 2010.

3. Gray RH, Kigozi G, Serwadda D, Makumbi F, Watya S, Nalugoda F, Kiwanuka N, Moulton LH, Chaudhary MA, Chen MZ, Sewankambo NK, Wabwire-Mangen F, Bacon MC, Williams CF, Opendi P, Reynolds SJ, Laeyendecker O, Quinn TC, Wawer MJ: Male circumcision for HIV prevention in men in Rakai, Uganda: a randomised trial. Lancet 2007, 369:657-666.

4. Bailey RC, Moses S, Parker CB, Agot K, Maclean I, Krieger JN, Williams CF, Campbell RT, Ndinya-Achola JO: Male circumcision for HIV prevention in young men in Kisumu, Kenya: a randomized controlled trial. Lancet 2007, 369:643-656.

5. Auvert B, Taljaard D, Lagarde E, Sobngwi-Tambekou J, Sitta R: Randomized, controlled intervention trial of male circumcision for reduction of HIV infection risk: the ANRS 1265 trial. PLOS Med 2005, 2:e298.

6. Weiss HA, Thomas SL, Munabi SK, Hayes RJ: Male circumcision and risk of syphilis, chancroid, and genital herpes: a systematic review and meta-analysis. Sex Transm Infect 2006, 82:101-109. discussion 110.

7. Sobngwi-Tambekou J, Taljaard D, Nieuwoudt M, Lissouba P, Puren A, Auvert B: Male circumcision and Neisseria gonorrhoeae, Chlamydia trachomatis and Trichomonas vaginalis: observations after a randomised controlled trial for HIV prevention. Sex Transm Infect 2009, 85:116-120.

8. Gray RH, Kigozi G, Serwadda D, Makumbi F, Nalugoda F, Watya S, Moulton L, Chen MZ, Sewankambo NK, Kiwanuka N, Sempijja V, Lutalo T, Kagayii J, Wabwire-Mangen F, Ridzon R, Bacon M, Wawer MJ: The effects of male circumcision on female partners' genital tract symptoms and vaginal infections in a randomized trial in Rakai, Uganda. Am J Obstet Gynecol 2009, 200(42):e41-47.

9. WHO and UNAIDS: New data on male circumcision and HIV prevention: policy and programme implications: conclusions and recommendations. [Technical consultation]. In World Health Organisation and Joint United Nations Programme on HIV/AIDS. Geneva: World Health Organisation; 2007.

10. Galukande M, Sekavuga DB, Duffy K, Wooding N, Rackara S, Nakaggwa F, Nagaddya T, Elobu AE, Coutinho A: Mass safe male circumcision: early lessons from a Ugandan urban site - a case study. Pan Afr Med J 2012, 13:88.

11. Kitara D, Lagoro L, Ocero A, Lanyero J, Ocom F: Roll-out of Medical Male circumcision (MMC) for HIV prevention in non-circumcising communities of Northern Uganda. Pan Afr Med J 2013, 15.

12. $\mathrm{MOH}$ and ICF International: Uganda AIDS Indicator Survey 2011. Kampala, Uganda and Calverton Maryland, USA: Ministry of Health and ICF International; 2012.

13. $\mathrm{MOH}$ and ORC Macro: Uganda HIV/AIDS Sero-behavioural Survey 2004-2005. Calverton, Maryland, USA: Ministry of Health and ORC Macro; 2006.

14. Bonner K: Male circumcision as an HIV control strategy: not a 'natural condom'. Reprod Health Matters 2001, 9:143-155.

15. Hedlund J: Risky business: safety regulations, risk compensation, and individual behavior. Inj Prev 2000, 6:82-90.

16. Adams J, Hillman M: The risk compensation theory and bicycle helmets. Inj Prev 2001, 7:343.

17. Riess HT, Achieng MM, Otieno S, Ndinya-Achola JO, Bailey CR: "When I was circumcised I was taught certain things": risk compensation and protective sexual behavior among circumcised Men in kisumu, kenya. PLOS ONE 2010, 5

18. Cassell MM, Halperin DT, Shelton JD, Stanton D: Risk compensation: the Achilles' heel of innovations in HIV prevention? BMJ 2006, 332:605-607.

19. Eaton L, Kalichman SC: Behavioral aspects of male circumcision for the prevention of HIV infection. Curr HIV/AIDS Rep 2009, 6:187-193.

20. Chikutsa A, Alfred NC, Mutsau S: Male Circumcision and Risky Sexual Behavior in Zimbabwe: evidence from the 2010-11 Zimbabwe Demographic and Health Survey. In DHS working Papers, Volume 2013. Calverton, Maryland, USA: ICF International; 2013

21. Kong X, Kigozi G, Nalugoda F, Musoke R, Kagaayi J, Latkin C, Ssekubugu R, Lutalo T, Nantume B, Boaz I, Wawer M, Serwadda D, Gray R: Assessment of changes in risk behaviors during 3 years of posttrial follow-up of male circumcision trial participants uncircumcised at trial closure in Rakai, Uganda. Am J Epidemiol 2012, 176:875-885.

22. Bailey RC, Neema S, Othieno R: Sexual behaviors and other HIV risk factors in circumcised and uncircumcised Men in Uganda. J Acquir Immune Defic Syndr 1999, 22:213-315.

23. Kalichman S, Eaton L, Pinkerton S: Circumcision for HIV prevention: failure to fully account for behavioral risk compensation. PLOS Med 2007, 4(3):595-601.

24. Sidler D, Smith J, Rode H: Neonatal circumcision does not reduce HIV/AIDS infection rates. SAMJ 2008, 98:762-766.

doi:10.1186/1742-4755-11-25

Cite this article as: Kibira et al:: Differences in risky sexual behaviors and HIV prevalence of circumcised and uncircumcised men in Uganda: evidence from a 2011 cross-sectional national survey. Reproductive Health 2014 11:25

\section{Submit your next manuscript to BioMed Central and take full advantage of:}

- Convenient online submission

- Thorough peer review

- No space constraints or color figure charges

- Immediate publication on acceptance

- Inclusion in PubMed, CAS, Scopus and Google Scholar

- Research which is freely available for redistribution 